\title{
Conflicts of Interest: Slicing the Hot Potato Doctrine
}

\author{
JOHN LEUBSDORF*
}

\section{TABLE OF CONTENTS}

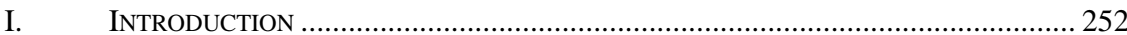

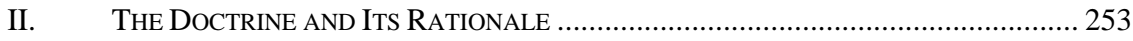

A. $\quad$ The Doctrine and the Model Rules ....................................................... 254

B. Purposes of the Doctrine .................................................................... 257

III. BEyond the PARAdigm CASE: THE DoctRine’s BoundariES .......................... 260

A. What if the Firm Drops Its Old Client Before Accepting

the New Client?............................................................................................. 261

B. What if the Protesting Client Discharges the Firm? .............................. 264

C. What if the Firm Did Not Cause the Conflict?........................................ 267

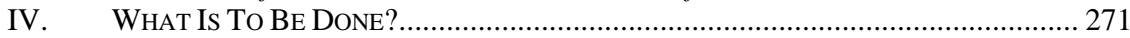

A. Judicial Discretion and Its Alternatives................................................. 272

B. What Courts Should Consider in Exercising Discretion ............................ 275

1. Balancing Client Burdens .............................................................. 275

2. Discounting or Emphasizing Client Burdens .................................... 276

3. Reducing Client Burdens ........................................................... 277

4. The Firm's Fault .................................................................................. 279

5. Quasi-Clients: Corporate Affiliates ................................................. 279

6. Quasi-Clients: Accommodation Clients ........................................... 281

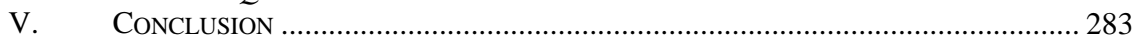

* Professor of Law, Rutgers School of Law-Newark. Thanks to Geoffrey C. Hazard, Jr., Nancy J. Moore, and Henry Bryans for their helpful comments. 


\section{INTRODUCTION}

"A firm may not drop a client like a hot potato, especially if it is in order to keep happy a far more lucrative client." ${ }^{2}$ Like other similes, these words of Judge Ann Aldrich have proved both persuasive and obfuscating. Many courts have relied on them in addressing claims that a law firm seeks to manipulate conflict of interest rules for its own profit. Yet the simile's impact has tended to cloud analysis of the issues it raises and has shifted attention from the purposes of conflicts of interest rules to the motives of the lawyers.

This essay, which boasts of being the first law review article devoted to what professional responsibility insiders call the "hot potato doctrine," will discuss some of the unanswered questions about the doctrine's core principle: a firm may not turn a present client into a former client by "firing" the client in order to get the benefit of the more lenient conflict of interest rules that apply to former clients. Exactly how does this modify the rules laid down by the Model Rules of Professional Conduct governing conflicts of interest and withdrawal from representations? What is the justification for refusing to apply the former client conflict rule to someone who is, after all, a former client? Should the doctrine be applied if it is the client who reacts to the conflict of interest by discharging the law firm, rather than the firm that withdraws? Does it matter if the firm dropped one client before accepting another, so that there has never been a time at which it represented two clients with conflicting interests? Should the doctrine apply when the conflict has been brought about by a client rather than a lawyer or when the lawyers involved have done their best to avoid the conflict? And when the doctrine does apply, which of the two clients whose interests conflict should be the one to lose the services of the firm?

The subject of this discussion is one of the few to which my friend Fred Zacharias did not bring his insight and incredible energy. So far as I can tell, his many writings make only one passing reference to the doctrine. $^{2}$ But he did raise deep questions about conflict of interest rules. $^{3} \quad$ He also wrote illuminatingly about broad principles of professional responsibility that proclaim more than closer consideration

1. Picker Int'l, Inc. v. Varian Assocs., 670 F. Supp. 1363, 1365 (N.D. Ohio 1987), aff'd, 869 F.2d 578 (Fed. Cir. 1989). The sentence in the text has been quoted in many later opinions.

2. See Bruce A. Green \& Fred C. Zacharias, Permissive Rules of Professional Conduct, 91 MinN. L. REV. 265, 287 (2006).

3. See, e.g., Fred C. Zacharias, Coercing Clients: Can Lawyer Gatekeeping Rules Work?, 47 B.C. L. REV. 455 (2006); Fred C. Zacharias, Waiving Conflicts of Interest, 108 YALE L.J. 407 (1998). 
can justify ${ }^{4}$ or than can be enforced in the real world. ${ }^{5}$ And for all his interest in theory, he rejoiced in probing the details of professional rules. $^{6}$ So I hope that he would have appreciated this small contribution, written in his honor, to the field to which he devoted most of his professional life.

\section{THE DOCTRINE AND ITS RATIONALE}

We begin with the paradigm situation that the hot potato doctrine addresses. Firm represents Potato, Inc. in ongoing tax matters. Another corporation, Mammoth, Inc., retains Firm to bring a major antitrust suit, and it turns out that Potato, Inc. should be one of the defendants. Firm cannot, absent informed consent by both clients, represent Potato, Inc. in one matter and sue it in another, even though the matters are wholly unrelated and involve no overlapping confidential information. That is the concurrent conflict rule presently embodied in Model Rule 1.7(a)(1)'s ban on representing a client when "the representation of one client will be directly adverse to another client.",

The hot potato doctrine prevents Firm from escaping this rule by dropping Potato and thus turning it into a former client. Normally, a law firm is free to represent a client against a former client so long as the matters in question are not substantially related. Matters are substantially related, with possible rare exceptions, only when it is likely that confidential information the firm obtained while representing the former client can be used against it in the present representation, or when the present representation requires the firm to demolish what it accomplished in the

4. See, e.g., Fred C. Zacharias, Rethinking Confidentiality, 74 IOWA L. REV. 351 (1989); Fred C. Zacharias, Specificity in Professional Responsibility Codes: Theory, Practice, and the Paradigm of Prosecutorial Ethics, 69 Notre DAmE L. Rev. 223 (1993); Fred C. Zacharias, The Preemployment Ethical Role of Lawyers: Are Lawyers Really Fiduciaries?, 49 WM. \& MARY L. REV. 569 (2007).

5. See, e.g., Fred C. Zacharias, The Future Structure and Regulation of Law Practice: Confronting Lies, Fictions, and False Paradigms in Legal Ethics Regulation, 44 ARIZ. L. REV. 829 (2002).

6. See, e.g., Green \& Zacharias, supra note 2; Fred C. Zacharias, A Critical Look at Rules Governing Grand Jury Subpoenas of Attorneys, 76 MinN. L. REV. 917 (1992).

7. Model Rules of PROF'L CONDUCT R. 1.7(a)(1) (2010). For earlier authority, see International Business Machines Corp. v. Levin, 579 F.2d 271 (3d Cir. 1978); Flatt v. Superior Court, 885 P.2d 950 (Cal. 1994); Grievance Committee v. Rottner, 203 A.2d 82 (Conn. 1964); Charles W. Wolfram, Modern Legal Ethics 351-52 (1986); and Thomas D. Morgan, Suing a Current Client, 9 GEO. J. LegAL ETHICs 1157 (1996), which criticizes the rule in its absolute form. 
previous one, for example, by invalidating a patent it helped the former client obtain. ${ }^{8}$ Under this rule, Firm would be free to represent Mammoth in its suit against Potato after terminating its representation of Potato because the matters in which Firm represented Potato are entirely unrelated to the current antitrust suit. But Potato can persuade the court to disqualify Firm from representing Mammoth against it by arguing that Firm should not have dropped it like a hot potato, so that the concurrent representation rule applicable to present clients should still apply. ${ }^{9}$

\section{A. The Doctrine and the Model Rules}

The hot potato doctrine both builds on and modifies the Model Rules of Professional Conduct, providing an example of the interplay between rulemakers and courts that until very recently has been central to the regulation of the bar. ${ }^{10}$ As just explained, the doctrine arises from the discrepancy between the stringent disqualification rule barring representations against a current client-Model Rule 1.7(a)—and the more lenient rule applicable to representations adverse to former clients-Model Rule 1.9(a). That discrepancy tempts some law firms to turn a current representation into a past representation, and the hot potato doctrine guards against that temptation. It would be interesting to consider what other professional rules create similarly perverse incentives, but not here. ${ }^{11}$

8. See Model Rules of Prof'l Conduct R. 1.9(a) \& cmt. 3 (2010); RESTATEMENT (THIRD) OF THE LAW GOVERNING LAWYERS $\S 132$ (2000). The rule is usually traced back to T.C. Theatre Corp. v. Warner Bros. Pictures, Inc., 113 F. Supp. 265, 268-69 (S.D.N.Y. 1953). For its development, see WolfRAM, supra note 7, at 358-71.

9. See, e.g., RESTATEMENT (THIRD) OF THE LAW GOVERNING LAWYERS § $132 \&$ cmt. c (2000); Ronald D. Rotunda \& John S. DzIENKOWSKI, PROFESSIONAL RESPONSIBILITY: A STUDENT's GUIDE $§ 1.7-5$ (2008). There is a bit of contrary authority. See, e.g., Monaghan v. SZS 33 Assocs., No. 89 Civ. 4900 (RWS), 1994 WL 623185 (S.D.N.Y. Nov. 9, 1994); Pearson v. Singing River Med. Ctr., Inc., 757 F. Supp. 768 (S.D. Miss. 1991); In re Dayco Corp. Derivative Sec. Litig., 102 F.R.D. 624 (S.D. Ohio 1984). In Texas, the concurrent representation rule is limited to substantially related cases, so the problem does not arise. See Texas Disciplinary Rules of Prof'L CONDUCT R. 1.06(b) (2010).

10. See John Leubsdorf, Legal Ethics Falls Apart, 57 Buff. L. Rev. 959, 965-69, 1022-24, 1031-34 (2009); John Leubsdorf, Legal Malpractice and Professional Responsibility, 48 RUTGERS L. REV. 101, 106-08, 117-20 (1995).

11. See, e.g., John Leubsdorf, Against Lawyer Retaining Liens, 72 FORDHAM L. REV. 849, 861-62 (2004) (explaining how lien discourages clients from letting lawyers possess documents and property); Carol M. Rice, The Superior Orders Defense in Legal Ethics: Sending the Wrong Message to Young Lawyers, 32 WAKE FOREST L. REV. 887 (1997) (explaining how Model Rule 5.2(b) encourages associates to follow improper partner orders). 
We should not forget that the discrepancy between the past and present conflict rules exposes clients to a contrary temptation. By claiming that a law firm still represents them in one matter, clients can invoke the concurrent representation rule to prevent the firm from representing an adversary against them in another, unrelated matter. For example, they can argue that the first matter has not been concluded and that, even if it has been, the firm has a continuing relationship with its client, as opposed to representing it only in discrete matters. ${ }^{12}$ Some firms increase their clients' temptation by leaving it unclear whether the end of a particular job is also the end of the representation as a whole, thus encouraging clients to continue regarding the firm as their lawyer, or at least to claim that they do. ${ }^{13}$

Two more Model Rules lurk underneath the hot potato doctrine in different ways. The vicarious disqualification rule, by extending the prohibition of conflicting concurrent representations by an individual lawyer to every lawyer in that lawyer's firm, ensures that the hot potato problem will be a recurring one for large firms. ${ }^{14}$ Not only will increasing size increase exponentially the possibilities of a conflict, but it will also pit against each other the firm's department hoping to benefit from the new client and the department hoping to retain the old one. ${ }^{15}$ Virtually all the reported hot potato cases involve firms that are both large and nationally known. And in virtually all the cases, each representation of the offending firm was handled by a different lawyer.

12. See, e.g., SWS Fin. Fund A v. Salomon Bros., 790 F. Supp. 1392 (N.D. Ill. 1992) (finding continuing representation, but denying disqualification on other grounds); Artromick Int'l, Inc. v. Drustar, Inc., 134 F.R.D. 226, 229-32 (S.D. Ohio 1991) (finding representation had ended); Manoir-Electroalloys Corp. v. Amalloy Corp., 711 F. Supp. 188, 193-95 (D.N.J. 1989) (finding continuing representation).

13. See SUSAN P. SHAPIRO, TANGLED LOYALTIES: CONFLICT OF INTEREST IN LEGAL Practice 192-99 (2002); see also 26 ABA/BNA LAW. MANUAl Prof'L CONDUCT, Conflicts of Interest: Representation Adverse to Existing Client 512, 512-17 (2010) (explaining that although most lawyers would prefer to leave the door open for former clients to come back, the cost of being foreclosed from future representation in unrelated matters adverse to clients who may never return should also be considered).

14. Model Rules of Prof'L CONDUCT R. 1.10(a) (2010).

15. See SHAPIRO, supra note 13, at 188-91 (describing ways of managing potential conflicts). I owe this reference and some others to a law student paper, Henry M. Kelln, Dropping the Hot Potato: Rescusitating [sic] the Permissive Withdrawal Rules in the Model Rules of Professional Conduct (Berkeley Elec. Press, Working Paper No. 1164, 2006), available at http://law.bepress.com/expresso/eps/1164. 
That is why I refer to the entity whose professional conduct is in question as a firm, not a lawyer. ${ }^{16}$

Lastly, Model Rule 1.16, specifying when a firm may or must withdraw from a representation, seems to offer a way to resolve the hot potato problem without any need to create doctrine. ${ }^{17}$ After all, does not that rule tell us just when a firm may withdraw from a representation? As we shall soon see, things are not that simple. ${ }^{18}$ Nevertheless, that lawyers are not free to withdraw from representations at will is one of the rules giving rise to the hot potato problem. ${ }^{19}$

Although based on the concurrent and past representation conflicts rules, the hot potato doctrine clearly modifies them by directing that, in some circumstances, the concurrent representation rule will govern even though one representation has ended. This raises a central question about the doctrine: once the concurrent representation specified by Model Rule 1.7(a) no longer exists, and the problems addressed by that rule have ended, why should the rule apply? The answer to that question will not only determine whether the hot potato doctrine deserves to live but will surely influence its scope.

The doctrine also modifies the model rules governing conflicts of interest by implementing the remedy of disqualification. The Model Rules themselves specify only the remedy of lawyer discipline. ${ }^{20}$ I have been able to find only two decisions invoking the hot potato doctrine to discipline a lawyer. ${ }^{21}$ Motions to disqualify have been virtually the exclusive forum for development of the doctrine. It has consequently been applied only in situations in which at least one of the representations involves litigation. $^{22}$ As a result, the doctrine is judge-made and has therefore developed both flexibilities and inconsistencies. An added

16. See John Leubsdorf, Pluralizing the Client-Lawyer Relationship, 77 CORNELL L. REV. 825 (1992) (critiquing the tendency to think of ethics in terms of "the lawyer" and "the client" when these entities are often plural).

17. See MOdel Rules OF PROF’L CONDUCT R. 1.16 (2010).

18. See infra Part III(A).

19. In France, a lawyer may always withdraw, provided that the client receives due notice. André Damien \& Henri Ader, RÈgles de la Profession D’AVOcAt § 91.11 (10th ed. 2004).

20. See Model Rules of Prof'l Conduct pmbl. paras. 14, 19, 20, \& R. 8.4 (2010).

21. See Bd. of Prof'l Ethics \& Conduct v. Winkel, 599 N.W.2d 456 (Iowa 1999) (not using the phrase "hot potato"); In re Johnson, 2004 MT 6, 319 Mont. 188, 84 P.3d 637. Likewise, there seem to be no reported decisions granting injunctive or damages relief for violations of the doctrine.

22. See Maritrans GP Inc. v. Pepper, Hamilton \& Scheetz, 602 A.2d 1277 (Pa. 1992) (enjoining a firm that dropped an old client for a new one, but failing to apply the hot potato doctrine because the old and new representations were related); see also Airgas, Inc. v. Cravath, Swaine \& Moore LLP, No. 10-612 (E.D. Pa. Aug. 3, 2010) (pending damages claim with hot potato issues). 
layer of flexibility results from authority in many jurisdictions providing that, even if the court finds that a law firm acted unprofessionally, it has discretion whether to require the firm to withdraw. ${ }^{23}$

\section{B. Purposes of the Doctrine}

At least three untenable justifications for the hot potato doctrine come to mind. First, although many of the conflict of interest rules protect clients against misuse of their confidences, that clearly could not justify the hot potato doctrine, which makes a difference only when the two representations giving rise to the problem are unrelated in the sense that confidences received from one client have no use against the other. If the two representations were related, rule 1.9(a) would bar the second representation even if the first representation were long past, and there would hence be no need to invoke the concurrent representation rule. ${ }^{24}$

Second, the assertion that firms may not drop one client like a hot potato "in order to keep happy a far more lucrative client" suggests that the doctrine targets lawyer greed. ${ }^{25}$ No doubt distaste for greed helps explain why judges have imposed disqualification, but as a justification it falls short. If courts seek to step in whenever a lawyer acts out of greed, the hot potato doctrine will have to be placed on a huge menu of other new doctrines. Our system of professional responsibility has never forbidden the aspiration to become wealthy through the practice of law, though we should honor those with other goals. ${ }^{26}$ Payment, of course, may not be sought through improper means, but that simply returns us to the question why dropping one client for the sake of another is sufficiently improper to warrant forbidding the new representation.

23. See infra Part IV; see generally RICHARD E. FLAMM, LAWYER DISQUALIFICATION: CONFLICTS OF INTEREST AND OTHER BASES §§ 23-25 (2003 \& Supp. 2010) (identifying and describing various lawyer disqualification standards).

24. See, e.g., In re Compact Disc Minimum Advertised Price Antitrust Litig., No. MDL 1361, 2001 WL 243494, at *14 \& n.8 (D. Me. Mar. 12, 2001) (disqualifying counsel under prior client rule while observing that hot potato doctrine might also apply); Santacroce v. Neff, 134 F. Supp. 2d 366, 371-72 (D.N.J. 2001) (holding that even if concurrent representation rule does not apply, the past representation rule requires disqualification); supra note 8.

25. Picker Int'l, Inc. v. Varian Assocs., 670 F. Supp. 1363, 1365 (N.D. Ohio 1987), aff'd, 869 F.2d 578 (Fed. Cir. 1989).

26. Cf. John LeUBSDORF, Man in His Original Dignity: Legal Ethics in FranCe 17-22 (2001) (describing the traditional French view that lawyers should be financially “disinterested”). 
Third, protecting "the integrity of the legal profession and its high standing in the community"27 likewise begs the question: why is the integrity of the profession impaired when a firm applies the former client rule to a former client? Admittedly, there might be a problem if the firm made a client into a former client through a forbidden withdrawal, but the withdrawal rule not only allows but also requires withdrawal if continuing the representation "will result in violation of the Rules of Professional Conduct" and that of course includes a violation of the conflict of interest rules. ${ }^{28}$ Once again, if the withdrawal is proper, why does a greedy motivation call for judicial relief?

A more persuasive justification for the doctrine looks away from the circumstances in which the firm left its old client-circumstances on which the phrase "drop a client like a hot potato" ${ }^{29}$ confusingly focuses our attention - to those in which the firm accepted its new client. In the paradigm case we are considering, ${ }^{30}$ that acceptance violates the concurrent representation conflicts rule: the firm is undertaking to represent its new client in litigation against its existing client. ${ }^{31}$ For the court to disqualify the firm from its new and unlawful representation can hence be justified as depriving it of the fruits of its violation, and deterring it and other firms from misbehaving similarly in the future. And relying on the unlawful new representation to establish a conflict of interest that the firm invokes as a reason to withdraw from the old representation only aggravates the offense.

A significant deterrent is appropriate when the victimized client seeks a remedy because in many instances no remedy will be sought. Faced with the desertion of its lawyers, the old client may simply wish them good riddance without trying to retain its faithless representatives or undergoing the expense of legal proceedings. This may happen before the firm even accepts the new client: simply telling the old client that it wishes to represent an adversary may be sufficiently discouraging to induce the old client to remove the problem by granting a somewhat pressured consent. $^{32}$ Indeed, with all respect for the difficulties of

27. El Camino Res., Ltd. v. Huntington Nat'l Bank, 623 F. Supp. 2d 863, 883 (W.D. Mich. 2007) (quoting Int'l Bus. Mach. Corp. v. Levin, 579 F.2d 271, 283 (3d Cir. 1978)); see also Argue v. David Davis Enters., No. 02-9521, 2004 WL 2480836 (E.D. Pa. Nov. 4, 2004) (invoking “public confidence in the judicial system”); Lemelson v. Apple Computer, Inc., No. CV-N-92-665-HDM (PHA), 1993 WL 556452 (D. Nev. June 2 , 1993) (relying on similar language).

28. Model Rules of PROF'L CONDUCt R. 1.16(a)(1) (2010).

29. Picker Int'l, 670 F. Supp. at 1365.

30. See supra text accompanying note 7.

31. See Model Rules OF PROF'L Conduct R. 1.7(a)(1) (2010).

32. Model Rule of Professional Conduct 1.7(b) usually allows informed consent to conflicting concurrent representations, but firms do not always obtain adequate consent. 
switching lawyers, one might well suspect a client that insists on staying with a firm that wants to reject it, especially when the client simultaneously seeks to disqualify the firm from another representation-this might be called the clinging potato problem. Actually, the client will need to retain a new firm simply to press its challenge to the old firm, so the temptation will be all the greater to forgo the expense of seeking to recapture the latter.

Alternatively, the firm may be able to avoid an attack on its conduct by bringing old representations to an end, or persuading the old clientwith more or less fidelity to its interests - to settle pending cases, making it possible to accept the new client without any conflict of interest. The new client's case may also settle before the conflicts issue is adjudicated. And as already noted, lawyer discipline is unlikely in hot potato cases. $^{33}$ So when a party does protest and the court finds a violation, sanctions of some vigor are appropriate.

Aside from deterring violations, disqualification can sometimes be justified as implementing the policies on which the concurrent representation rule is based. One of those policies is that it is hard to trust and cooperate with a firm that is simultaneously opposing one, even in an unrelated matter. Clients do not have an unbounded right to lawyer loyalty, and representing a client once does not bind a lawyer forever to avoid acts offensive to the client. But a client should not have to brace itself against direct and simultaneous opposition from its lawyer.

Of course, once the lawyer drops the client, this problem disappears. But is not the fear of being dropped in this way by a lawyer who then represents one's adversary part of precisely the distrust against which the concurrent representation rule guards? If abandonment is allowed, will not the fear of abandonment contaminate the client-lawyer relationship while it still exists, before the lawyer deserts the client?

Less support for the hot potato doctrine can be gleaned from the other major policy underlying the concurrent representation conflict of interest rule: the possibility that a firm will act with diminished vigor when representing a client who is suing the firm's other client for fear that the

See id. R. 1.7(b). Compare In re Sandahl, 980 F.2d 1118 (7th Cir. 1992) (finding informed consent), with El Camino Res., Ltd. v. Huntington Nat'l Bank, 623 F. Supp. 2d 863 (W.D. Mich. 2007) (rejecting informed consent claim).

33. See supra text accompanying note 21 . 
other client will discharge the firm. ${ }^{34}$ As Thomas Morgan has pointed out, this possibility does not exist for every client in every case..$^{35}$ In the paradigm case we are considering, Mammoth, Inc., the new client suing Potato, Inc., might have some fear that Firm's relationship with Potato might impede its representation of Mammoth—but Mammoth is not objecting. Potato has no reason to fear that Firm will appease Mammoth by giving Potato poor representation in wholly unrelated matters in which Mammoth is not involved. Yet the hot potato doctrine enables Potato to bar Firm's representation of Mammoth.

One can however argue that the very fact that Firm has "fired" Potato shows that its representation of Potato has indeed been impaired-in fact, impaired to the vanishing point. The suffering comes not from any incentives brought to bear on Firm by its concurrent representations but rather from the conflict rule forbidding such representations. So the argument is a bit circular. Nevertheless, so long as the concurrent representation rule exists in its current rigor, there is much to be said for preventing Firm from attaining compliance at the expense of Potato, the very party that the rule seeks to protect.

In sum, disqualifying a firm from representing its new client in the paradigmatic hot potato situation can indeed be justified, primarily to deter firms from accepting new representations in violation of the concurrent representation rule. The policies underlying that rule are also implicated, albeit in complex and indirect ways. Ultimately, it makes little sense to have a rule protecting a client from harms that may follow should its lawyers represent its adversary in an unrelated matter if the result will be to encourage lawyers to jettison entirely the client sought to be protected. The hot potato doctrine prevents that from happening.

\section{BEyOND THE PARADIGM CASE: THE DOCTRINE's BOUNDARIES}

Several features make the paradigm case we have so far been considering an easy one. The firm in question has simultaneously represented two clients with opposing interests, in violation of the concurrent representation conflicts rule. The firm unilaterally resolved the conflict by dropping the old client in the midst of the representation. And the conflict resulted from the firm's own act in agreeing to represent a new client against an existing client. When we relax these requirements, new problems sprout from the hot potato doctrine, which

34. See, e.g., Int’l Bus. Mach. Corp. v. Levin, 579 F.2d 271, 280 (3d Cir. 1978); Estates Theatres, Inc. v. Columbia Pictures Indus., 345 F. Supp. 93, 99 (S.D.N.Y. 1972); RESTATEMENT (THIRD) OF THE LAW GOVERNING LAWYERS § 128 cmt. e (2000).

35. See Morgan, supra note 7. 
indeed begins to look less like a single entity and more like a heterogeneous salad.

\section{A. What if the Firm Drops Its Old Client Before Accepting the New Client?}

If a firm terminates one of the two representations that would otherwise conflict before starting the other representation, there has never been a time at which it was in violation of the concurrent representation rule. One could therefore argue that the firm has done nothing calling for a deterrent sanction. Nor has there been a period during which the dangers that the concurrent representation rule seeks to avoid could have existed. As a result, there is arguably no need to disqualify the firm from representing its new client.

Before the hot potato simile appeared on the ethical menu, as well as more recently, some courts applied a rule consistent with this argument, holding that whether the concurrent representation rule was violated should be judged as of the time the second representation commenced. ${ }^{36}$ A withdrawal after that date was therefore governed by the concurrent representation rule, ${ }^{37}$ while a previous withdrawal left the firm constrained only by the previous representation rule. ${ }^{38}$

If unsupplemented, this approach has the disadvantage that it disregards the grounds on which the firm withdrew. If the firm withdrew from its first representation without good cause and in breach of its obligations, it acted improperly even if it did so before accepting a new client. Disqualification is then appropriate, not to deter violation of the concurrent representation rule but to deter violation of the rule prohibiting withdrawal without good cause. ${ }^{39}$ On the other hand, even if a firm accepts the new client before withdrawing from representation of

36. See, e.g., Ransburg Corp. v. Champion Spark Plug Co., 648 F. Supp. 1040, 1043-45 (N.D. Ill. 1986).

37. See, e.g., EEOC v. Orson H. Gygi Co., 749 F.2d 620, 621 (10th Cir. 1984); Unified Sewerage Agency v. Jelco Inc., 646 F.2d 1339, 1345 n.4 (9th Cir. 1981); Qwest Corp. v. Anovian, Inc., No. C08-1715RSM, 2010 WL 1440765 (W.D. Wash. Apr. 8, 2010); Santacroce v. Neff, 134 F. Supp. 2d 366 (D.N.J. 2001) (alternate ground).

38. See, e.g., Pamlab, L.L.C. v. Hi-Tech Pharmacal Co., No. 08-cv-00967-REBBNB, 2009 WL 77527 (D. Colo. Jan. 9, 2009) (relying on lack of evidence that lawyer dropped old client to get new one); In re Agway, Inc., Bankruptcy Nos. 02-65872, 0265873, 02-65874, 02-65875, 02-65876, 02-65877, 2005 WL 3806043 (Bankr. N.D.N.Y. Dec. 9, 2005).

39. See Model Rules of Prof’́ Conduct R. 1.16 (2010). 
the old one, disqualification is inappropriate if it had cause to withdraw other than the conflict of interest that the firm itself created. For example, if the old client refuses after notice to pay its bills, the firm should be free to withdraw; arguably it should also be free to continue representing the new client despite having briefly engaged in a forbidden concurrent representation. ${ }^{40}$ The same may be true if the firm accepts the new client but then protects the old client's interests by parting from the lawyers who have been representing that client so that they can continue their representation. ${ }^{41}$

Geoffrey Hazard and his coauthors W. William Hodes and Peter Jarvis have proposed a modified time-of-discharge standard: retaining the hot potato doctrine in its existing form when the firm withdraws after improper concurrent representation has started, they would allow the firm to withdraw before then but only if it has good cause to withdraw. ${ }^{42}$ That good cause could not of course be the improper concurrent representation that the firm itself has created; there would be no such representation because the firm would have withdrawn from the old representation before starting the new one. But there could be other grounds for withdrawal. It might be that "withdrawal can be accomplished without material adverse effect on the interests of the client," or that "the client insists upon taking action... with which the lawyer has a fundamental disagreement"- other than the action of objecting to the proposed conflicting representations-or that the representation "has been rendered unreasonably difficult by the client," or that there is "other good cause for withdrawal." 43

As Hazard and his coauthors say in defense of this proposal, if the requirements for withdrawal are met, the rules "permit a lawyer to cease representation-assuming no harm to the client-for no reason or because the lawyer is bored or overworked or because more lucrative

40. See Rosewood Apartments Corp. v. Perpignano, No. 99 Civ. 4226 (NRB) (MHD), 2000 WL 145982 (S.D.N.Y. Feb. 3, 2000); RotUNDA \& DZIENKOWSKI, supra note 9, at 343; see also Eaton v. Coca-Cola Co., 640 F. Supp. 2d 203 (D. Conn. 2009) (stating that firm, having withdrawn from one representation, may also withdraw from other representation due to irrevocable breakdown of lawyer-client relationship). On nonpayment as a ground for withdrawal, see MODEL RULES OF PROF'L CONDUCT R. 1.16(b)(5).

41. See Hartford Accident \& Indem. Co. v. RJR Nabisco, Inc., 721 F. Supp. 534 (S.D.N.Y. 1989). But see Atl. Pac. Home Loans, Inc. v. Superior Court, No. D048609, 2006 WL 3616997 (Cal. Ct. App. Dec. 13, 2006) (upholding disqualification in somewhat similar circumstances).

42. 1 GeOfFrey C. HaZard, JR. et AL., The LaW OF LAWYering $§ 20.10$ (3d ed. 2001 \& Supp. 2010).

43. Model Rules of Prof'L Conduct R. 1.16(b)(1), (4), (6), (7). 
work presents itself." ${ }^{44}$ So a greedy firm should be free to switch clients-provided the matters in question are unrelated, the firm has cause to withdraw from the first representation, and it does so before starting the second representation.

One difficulty with this proposal is that it makes a lot turn on the precise time of withdrawal. If the firm does not succeed in effectuating its withdrawal before the moment at which the new representation starts, it gets mashed by the hot potato doctrine. ${ }^{45}$ If it withdraws with cause just before the new representation starts, it is in the clear even though the impact on all concerned is identical. It is not clear that courts will stick with such a rigid rule or that they should do so. And one can expect the old client and the firm to dispute the precise moment at which the old representation ended.

Even if a firm manages to consummate its withdrawal from one representation before formally instituting another, there will still in many cases be an intermediate period posing all the dangers against which the concurrent representation rule guards. The firm may put off its official acceptance of the new client, but it fully expects to represent that client and therefore takes its interests into account. ${ }^{46}$ Meanwhile, it will hasten to finish its work for the old client, perhaps urging a quick settlement, delaying new initiatives, trying to collect its fees, seeking that client's consent for it to withdraw, or establishing good grounds for withdrawal. $^{47}$ Whatever the formalities, in reality there will often be what amounts to concurrent representation of two parties whose interests conflict. In such situations, there is little reason to exempt the firm entirely from the hot potato doctrine.

A final but less serious difficulty with allowing a firm to withdraw for cause from one representation before starting a new one is that it

44. HAZARD, JR. ET AL., supra note 42, § 20.10, at 20-26 (Supp. 2010). Model Rule 1.16 allows withdrawal even if the client is harmed, unless withdrawal is based on the ground that there will be no "material adverse effect on the interests of the client." Model Rules of Prof'L CONDUCT R. 1.16(b)(1). The Restatement of the Law Governing Lawyers, by contrast, forbids withdrawal "if the harm that withdrawal would cause significantly exceeds the harm to the lawyer or others in not withdrawing." RESTATEMENT (THIRD) OF THE LAW GOVERNing LAWYERS § 32(4) (2000). But even under this provision, harm to the client does not necessarily bar withdrawal. See id.

45. See, e.g., Stratagem Dev. Corp. v. Heron Int'l N.V., 756 F. Supp. 789 (S.D.N.Y. 1991)

46. See SHAPIRO, supra note 13, at 189-90 (describing such delaying practices).

47. See Wong v. Fong, 593 P.2d 386 (Haw. 1979) (settling of one case after disqualification order in second case made disqualification unnecessary). 
encourages firms to claim cause for withdrawal on flimsy grounds. The withdrawal rules allow a firm to end a representation if that will not harm the client, even if there is no other basis for withdrawal. ${ }^{48}$ And even if the client will be harmed, the firm may withdraw on fuzzy grounds such as fundamental disagreement, unreasonable financial burden on the lawyer, or client behavior making the representation unreasonably difficult. ${ }^{49}$

It is doubtful, however, that tinkering with the hot potato doctrine will remedy the defects of the withdrawal rule. To the extent that the rule makes withdrawal too easy, it is the rule that needs remodeling, and fixing it would also remedy the many situations in which the hot potato doctrine does not apply. Indeed, cooked-up grounds for withdrawal may be less of a problem in hot potato cases than elsewhere: the doctrine is almost always invoked in a contested motion to disqualify counsel, and the court will then look into whether the firm's claim of cause to withdraw is borne out by the facts. A firm whose asserted cause to withdraw from one representation appears just after the firm is offered another inconsistent representation will be met with skepticism even by a court recognizing that lawyer cupidity is not in itself a ground for disqualification. That skepticism is appropriate and should foil fudged claims that firms are entitled to withdraw.

In short, I think that it often makes sense to allow a firm having cause to withdraw from a representation to do so and then accept a new and inconsistent representation. But when the deserted client seeks to disqualify the firm from the new representation, courts should appraise with care whether there really was cause to withdraw. And in considering whether withdrawal preceded the new representation, courts should look beyond formalities to determine whether the firm was involved with both clients simultaneously for a significant period. If so, the usual version of the hot potato doctrine should apply.

\section{B. What if the Protesting Client Discharges the Firm?}

There is some authority that, if the old client discharges the firm engaged in conflicting concurrent representations, the hot potato doctrine does not apply, and the firm is subject only to the less

48. Model Rules of Prof'L Conduct R. 1.16(b)(1). For a discussion of what should count as harm to the client, see RESTATEMENT (THIRD) OF THE LAW GOVERNING LAWYERS $\S 32 \mathrm{cmt}$. h(ii) (2000).

49. Model Rules of Prof'L Conduct R. 1.16(b)(4), (6). For attempts to limit such provisions, see RESTATEMENT (THIRD) OF THE LAW GOVERNING LAWYERS $\S 32$ cmts. h(i), j, l, m (2000). 
constraining rule governing former clients. ${ }^{50}$ After all, the firm has not dropped its client like a hot potato. Rather, the client itself chose to jump back into the pot. By its own doing, the problems of concurrent representation have ended. Now that the client no longer faces such problems, why should it be permitted to prevent its former lawyer from opposing it in an unrelated case? Doing so would burden its opponent in that case and is probably being sought for precisely that reason.

Yet equal and opposite authority favors the contrary position that the firm continues to be barred from opposing its client even though that client has discharged it. ${ }^{51}$ "Otherwise, counsel could simply persist in dual representation until one client or the other capitulates. Counsel should not be rewarded for delaying resolution of a conflict issue by being accorded a less demanding disqualification standard." ${ }^{\text {,2 }}$ Before its discharge, the firm violated the concurrent representation rule, misconduct that stands in need of deterrence. By seeking new counsel, its former client was simply protecting itself against the dangers of concurrent representation to which the firm wrongly exposed it, in the process bearing the further burdens of changing its lawyers. The concurrent representation rule gives it two rights: the right to retain its old firm in the absence of grounds for withdrawal and the right to prevent that firm from representing an opponent. It has abandoned the first right but still, in the absence of its own informed consent, retains the second one. ${ }^{53}$

Reconciling these concerns and arguments is not easy. Looking at the situation ex post-as it confronts the court deciding a motion to disqualify - it is hard to see that disqualification will prevent any real dangers. What it will do is to impose costs, both on the disqualified firm

50. See, e.g., Wal-Mart Stores, Inc. v. Vidalakis, No. 07-0039, 2007 WL 4468688 (W.D. Ark. Dec. 17, 2007); Coke v. Equity Residential Props. Trust, 800 N.E.2d 280 (Mass. 2003); RotUNDA \& DZIENKOWSKI, supra note 9, at 343; see also Wong, 593 P.2d 386 (settling of one case, pending disqualification proceedings in second case, ended concurrent representation problem).

51. See, e.g., Merck Eprova AG v. ProThera, Inc., 670 F. Supp. 2d 201 (S.D.N.Y. 2009); Ransburg Corp. v. Champion Spark Plug Co., 648 F. Supp. 1040 (N.D. Ill. 1986); Fund of Funds, Ltd. v. Arthur Andersen \& Co., 435 F. Supp. 84, 95 (S.D.N.Y. 1974), aff'd in relevant part, 567 F.2d 225 (2d Cir. 1977).

52. Merck, 670 F. Supp. 2d at 209.

53. Compare In re Sandahl, 980 F.2d 1118 (7th Cir. 1992) (client consented), and Unified Sewerage Agency v. Jelco Inc., 646 F.2d 1339 (9th Cir. 1981) (similar), with Fla. Ins. Guar. Ass'n v. Carey Can., Inc., 749 F. Supp. 255 (S.D. Fla. 1990) (any consent was not informed), and Champion Spark Plug, 648 F. Supp. 1040 (similar). 
and on its more or less innocent new client. ${ }^{54}$ Looking ex ante-at firms deciding whether to accept new clients - the prospect of disqualification from the new representation even should their old client discharge them will exercise a wholesome deterrent effect. Such firms will be more likely to conduct adequate conflicts checks, seek informed consent from clients, and in its absence decline improper representations. As a result, fewer disqualification motions will be needed. Yet there is also a more dubious incentive: a flat disqualification rule will encourage clients to turn the hot potato doctrine into the hot potato game, seeking to manipulate the situation so as to impose an expensive disqualification on an opposing party.

On the whole, it seems to me that the ex post attitude is the more appropriate one for a court considering a motion to disqualify and that there should therefore be a presumption that the old client's discharge of the firm frees the firm to represent the new client. The increasing tendency to recognize that, even in the face of a clear professional violation, courts have discretion not to require disqualification shows that deterrence should not be increased indefinitely. ${ }^{55}$ For that matter, deterrence can also be provided by professional discipline, ${ }^{56}$ court sanctions other than disqualification, ${ }^{57}$ malpractice liability, ${ }^{58}$ and attorney fee forfeiture. ${ }^{59}$ More basically, a court should not be placed in the position of having no choice but to help the old client harm the new

54. An innocent client may be able to recover its costs from the offending firm, or at least avoid paying that firm for its services. See infra notes 58-59.

55. See supra note 23; infra Part IV.

56. See, e.g., In re Johnson, 2004 MT 6, 319 Mont. 188, 84 P.3d 637 (discipline for hot potato violation); see also Bd. of Prof'l Ethics \& Conduct v. Winkel, 599 N.W.2d 456 (Iowa 1999) (similar).

57. See 28 U.S.C. $\S 1927$ (2006) (stating that lawyers who multiply proceedings unreasonably and vexatiously may be held liable for resulting expenses and attorney fees). Compare Sanford v. Virginia, 689 F. Supp. 2d 802 (E.D. Va. 2010) (declining to sanction disqualified lawyer), with United States v. Associated Convalescent Enters., 766 F.2d 1342 (9th Cir. 1985) (sanctioning lawyer who failed to disclose that he would be witness)

58. See, e.g., Airgas, Inc. v. Cravath, Swaine \& Moore LLP, No. 10-612 (E.D. Pa. Aug. 3, 2010) (breach of fiduciary duty claim); Andre v. Golden, 750 So. 2d 1101 (La. Ct. App. 1999) (stating statute of limitations barred claim against lawyer who represented plaintiff in suit against parish for which he was district attorney); Conoco, Inc. v. Baskin, 803 S.W.2d 416, 422 (Tex. App. 1991) (noting possible damages remedy).

59. See, e.g., City of Little Rock v. Cash, 644 S.W.2d 229 (Ark. 1982) (holding that plaintiff's lawyer, who also represented defendant in other matters, was not entitled to statutory fee award), overruled in part, T\&T Chem. v. Priest, 95 S.W.3d 750 (Ark. 2003); Jeffry v. Pounds, 136 Cal. Rptr. 373 (Cal. Ct. App. 1977) (upholding fee forfeiture when firm representing client in personal injury suit represented client's wife in divorce). See generally RESTATEMENT (THIRD) OF THE LAW GOVERNING LAWYERS § 37 (2000). 
client for its own strategic benefit after the old client has brought to an end the representation protected by the concurrent representation rule.

Nevertheless, there may be situations in which the circumstances rebut the presumption against disqualification even after the old client has discharged the firm. Suppose, for example, that disqualification would not significantly harm the new client, which already has another firm on the job; that the new client was aware of the concurrent representation problem when it retained the firm; that the firm did its best or worst to keep the concurrent representation going as long as possible, for example, by not making prompt disclosure to the old client; and that the firm's untrustworthy behavior left the old client with little choice but to discharge it. In such a case, and even in some not going that far, disqualification will not harm the innocent new client and will be an appropriate sanction for exacerbated impropriety.

\section{What if the Firm Did Not Cause the Conflict?}

A number of cases concern conflicts of interest caused by a corporate client's merger after two representations, each entirely proper when commenced, are under way. ${ }^{60}$ This has given rise to what is called, in a concatenation of jargon, the "thrust upon" exception to the hot potato doctrine. $^{61}$

Again a paradigm example will clarify the exception and its reasons. Firm represents Spudco in its suit against Boiler, Inc. It also represents Fryer, Ltd. in entirely unrelated matters. During the suit, Fryer and Boiler decide to negotiate a merger, which is then consummated. ${ }^{62}$ Now

60. See, e.g., Installation Software Techs., Inc. v. Wise Solutions, Inc., No. 03 C 4502, 2004 WL 524829 (N.D. Ill. Mar. 2, 2004); Univ. of Rochester v. G.D. Searle \& Co., No. 00-CV-6161L(B), 2000 WL 1922271 (W.D.N.Y. Dec. 11, 2000), aff'd, 358 F.3d 919 (Fed. Cir. 2004); Carlyle Towers Condo. Ass'n v. Crossland Sav., FSB, 944 F. Supp. 341 (D.N.J. 1996); Gould, Inc. v. Mitsui Mining \& Smelting Co., 738 F. Supp. 1121 (N.D. Ohio 1990); Pennwalt Corp. v. Plough, Inc., 85 F.R.D. 264 (D. Del. 1980); see also D.C. Bar Legal Ethics Comm., Op. 272 (1997), available at http://www. dcbar.org/for_lawyers/ethics/legal_ethics/opinions/opinion272.cfm; RESTATEMENT (THIRD) OF THE LAW GOVERNING LAWYERS $\S 128$ illus. 4 (2000).

61. See Ass'n of the Bar of the City of New York, Comm. on Prof'l \& Judicial Ethics, Formal Op. 2005-05 (2005) [hereinafter ABCNY, Comm. on Prof'l \& Judicial Ethics], reprinted in 61 REC. Ass'N B. CiTY N.Y. 102 (2006); ROTUNDA \& DZIENKOWSKI, supra note 9, at 343; Charles W. Wolfram, Ethics 2000 and Conflicts of Interest: The More Things Change . . ., 70 TENN. L. REV. 27, 36-37 (2002).

62. I specify a full-fledged merger to avoid any argument that Fryer and Boiler continue to be separate corporations that should be treated separately for conflicts of 
Firm is representing Spudco in a suit against the merged corporation, which it continues to represent in other matters. It is hence violating the concurrent representation rule. ${ }^{63}$ Spudco gladly consents to the concurrent representation. But the merged Fryer-Boiler corporation declines to give informed consent and takes the opportunity to demand that Firm withdraw from the Spudco representation.

The merged corporation cannot argue that any confidential information is at stake - the matters in question being unrelated - or that Firm has any interest in representing it badly in order to curry favor with Spudcothere is no way in which any such bad representation could benefit Spudco. The merged corporation can, however, say that representation by a firm that is simultaneously scheming against it in another matter deprives it of the trust it is entitled to feel in its lawyers. ${ }^{64}$

In such situations, the authorities rely on the thrust upon exception to reject the claim of the merged corporation that it is entitled to disqualify Firm from representing its adversary. ${ }^{65}$ Firm did nothing wrong in accepting either client because it did so at a time when neither of its representations caused it to oppose another Firm client. Nor did Firm do anything to bring about the subsequent adversity, which resulted entirely from the unforeseen decision of Boiler and Fryer to merge. Because the hot potato doctrine's central purpose is to sanction firms that seek to accept new representations inconsistent with existing representations, that doctrine should have no application here. ${ }^{66}$ Nor should the merged corporation be able to use its own act creating the conflict to impose expense and delay on its adversary, Spudco, by forcing it to switch counsel in midsuit.

But this is the easy part; the difficulty is to say what rule should replace the hot potato doctrine's rigor. Under the D.C. Rules of Professional Conduct, Firm would be free to continue with both representations, assuming that the conflict was not reasonably foreseeable when representation started and that the concurrent representation does not violate another rule. ${ }^{67}$ If either client objects, it is free to discharge Firm and find other representation but not to insist that Firm withdraw from representing its adversary. ${ }^{68}$ Other authorities require Firm to end

\footnotetext{
interest purposes. For the dispute as to whether and when it should matter that such transactions result not in a single corporation but in a wholly owned subsidiary and its parent, see infra Part IV(B)(5).

63. Model Rules of Prof'L Conduct R. 1.7(a)(1) (2010).

64. For these arguments, see supra text accompanying notes 33-35.

65. See supra notes $60-61$.

66. See supra Part II(B).

67. See D.C. Rules of Prof’L Conduct R. 1.7(d) (2010).

68. See RESTATEMENT (THIRD) OF THE LAW GOVERNING LAWYERS §§ 31(2)(a), 32(1) cmt. B (2000). In a litigated matter, procedural rules will usually require the client
} 
the conflict but allow it to choose whether to do so by withdrawing from the Spudco suit or by dropping the merged corporation-like a hot potato or otherwise-and continuing to represent Spudco in its suit against that corporation. $^{69}$ More cagily, a comment to the $A B A$ Model Rules says that "[d]epending on the circumstances, the lawyer may have the option to withdraw from one of the representations" without saying when that is so. ${ }^{70}$ After balancing relevant factors, courts have usually accepted the firm's decision to drop the merged corporation in order to continue the suit against it on behalf of Spudco. ${ }^{71}$ But there is also authority indicating Firm has no choice and must drop the merged corporation. ${ }^{72}$

In my opinion, Firm should not be able to continue both representations, absent informed consent or court approval. Representing both clients violates the concurrent representation rule intended to protect the clients, and that remains so even if the concurrent representation came about without any sin by Firm. Granted that one representation must end, and assuming that the parties cannot agree which one that should be, the decision falls in the first instance on Firm, which should take into account all the relevant factors and especially the impact of withdrawal on each representation. ${ }^{73}$ In the paradigm case being considered, court approval will also be needed, either because the merged corporation seeks to disqualify Firm from representing Spudco or because Firm seeks leave to withdraw from that representation. At this point, judicial discretion comes into play, in ways to be discussed later. ${ }^{74}$

to obtain court approval before changing counsel. See MODEL RULES OF PROF'L Conduct R. 1.16(c) (2010); see also AnNotated Model Rules of Prof'l Conduct R $1.16 \mathrm{cmt}$. (6th ed. 2007) (citing cases).

69. See, e.g., ABCNY, Comm. on Prof'l \& Judicial Ethics, supra note 61 (providing guidance to lawyers as to which client to drop).

70. MOdEl Rules OF PROF’L CONDUCT R. 1.7 cmt. 5 (2010).

71. See, e.g., Univ. of Rochester v. G.D. Searle \& Co., No. 00-CV-6161L(B), 2000 WL 1922271 (W.D.N.Y. Dec. 11, 2000), aff'd, 358 F.3d 916 (Fed. Cir. 2004); Carlyle Towers Condo. Ass'n v. Crossland Sav., FSB, 944 F. Supp. 341 (D.N.J. 1996); Gould, Inc. v. Mitsui Mining \& Smelting Co., 738 F. Supp. 1121 (N.D. Ohio 1990); Pennwalt Corp. v. Plough, Inc., 85 F.R.D. 264 (D. Del. 1980).

72. See, e.g., Installation Software Techs., Inc. v. Wise Solutions, Inc., No. 03 C 4502, 2004 WL 524829 (N.D. Ill. Mar. 2, 2004) (rejecting firm's motion to withdraw); RESTATEMENT (THIRD) OF THE LAW GOVERNING LAWYERS § 132 illus. 11 (2000) (illustrating that Firm must withdraw unless clients consent). But see id. § 128 illus. 4 (stating that Firm "might be permitted to withdraw").

73. See ABCNY, Comm. on Prof'l \& Judicial Ethics, supra note 61.

74. See infra Part IV. 
Once we depart from the paradigm thrust upon situation, the courts have in general reached results compatible with the principle that the hot potato doctrine applies only when the firm in question has acted wrongfully. Thus, when acts of one client other than a corporate merger give rise to the conflict, courts find the conflict to have been thrust on the firm and do not apply the hot potato doctrine. ${ }^{75}$ On the other hand, they do apply the doctrine when the firm should have foreseen the conflict $^{76}$ or when it allowed the conflict to persist rather than immediately bringing it to the attention of both clients. ${ }^{77}$ Such behavior calls for deterrence and unnecessarily exposes clients to the dangers of conflicting concurrent representations.

Some courts apply the hot potato doctrine when a conflict results from the firm's acts in merging or making a lateral hire during the representation, but that application seems questionable. ${ }^{78}$ Mergers and hires are not professional misconduct, even if they do sometimes result

75. See, e.g., Commonwealth Scientific \& Indus. Research Org. v. Toshiba Am. Info. Sys., 297 F. App’x 970 (Fed. Cir. 2008) (involving client $A$ who disclosed agreement that it would indemnify defendant that firm was suing for client $B$ ); $\mathrm{Bd}$. of Regents of the Univ. of Neb. v. BASF Corp., No. 4:04CV3356, 2006 WL 2385363 (D. Neb. Aug. 17, 2006) (involving client $A$ who disclosed its claim to an exclusive license to the technology in dispute in the suit in which firm represented client $B$ ); AmSouth Bank, N.A. v. Drummond Co., 589 So. 2d 715 (Ala. 1991) (during firm’s representation of two clients in unrelated matters, one client sued the other in a third matter). For a more questionable example, see Sabrix, Inc. v. Carolina Cas. Ins. Co., No. CV-02-1470HU, 2003 WL 23538035 (D. Ore. July 23, 2003) (involving a firm representing $A$ against $B$ while firm's client in another case brought its insurer, $B$, into that case, and firm agreed to represent $B$ as well).

76. See, e.g., El Camino Res., Ltd. v. Huntington Nat’l Bank, 623 F. Supp. 2d 863 (W.D. Mich. 2007); Philadelphia Bar Ass'n, Prof'l Guidance Comm., Op. 2009-07 (2009), available at http://www.philadelphiabar.org/WebObjects/PBAReadOnly.woa/Contents/ WebServerResources/CMSResources/2009-7EthicsOpinion.pdf; Wolfram, supra note 61, at 36-37.

77. See, e.g., Fla. Ins. Guar. Ass’n v. Carey Can., Inc., 749 F. Supp. 255 (S.D. Fla. 1990); Harte Biltmore Ltd. v. First Pa. Bank, N.A., 655 F. Supp. 419 (S.D. Fla. 1987); see also Flying J Inc. v. TA Operating Corp., No. 1:06-CV-30 TC, 2008 WL 648545 (D. Utah Mar. 10, 2008) (involving firm that sought no waiver or withdrawal for a year but disqualification denied for other reasons).

78. See, e.g., Harte Biltmore, 655 F. Supp. 419 (applying hot potato doctrine when conflict was not detected at time of law firm merger because client's name was misspelled). Compare Picker Int'l, Inc. v. Varian Assocs., 670 F. Supp. 1363 (N.D. Ohio 1987) (coining the hot potato simile and applying the doctrine when the conflict resulted from a law firm merger), and Qwest Corp. v. Anovian, Inc., No. C08-1715RSM, 2010 WL 1440765 (W.D. Wash. Apr. 8, 2010) (requiring disqualification when lawyers switched firms), with Pamlab, L.L.C. v. Hi-Tech Pharmacal Co., No. 08-cv-00967-REBBNB, 2009 WL 77527 (D. Colo. Jan. 9, 2009) (relying, inter alia, on conclusion that lawyer's primary motive in shifting firms was not to represent new client), and Monaghan v. SZS 33 Assocs., No. 89 Civ. 4900 (RWS), 1994 WL 623185 (S.D.N.Y. Nov. 9, 1994) (treating lateral hire as innocent cause of conflict). 
in conflicts of interest, always provided that the firm acts promptly to resolve the conflict. ${ }^{79}$

Although the thrust upon exception is usually discussed in connection with the hot potato doctrine, similar situations arise whenever developments for which a firm is not to blame cause a conflict of interest to arise during a representation. For example, a firm preparing wills for a husband and wife might learn that the husband had an illegitimate child with another woman, giving the spouses conflicting interests. ${ }^{80}$ Developments during a case may create $\operatorname{conflicts}^{81}$ or may cause a representation to become adverse to a former client. ${ }^{82}$ Each of these situations challenges the court to enforce basic professional requirements while avoiding needless disruption of representations that were started without any impropriety. The effect of the thrust upon principle is to free courts and lawyers to do this unconstrained by the more punitive approach that is applied when wrongdoing by the lawyers helps to create the conflict.

\section{WHAT IS TO BE DONE?}

The actual impact of the hot potato doctrine is more limited than might be expected from the assertion that "a firm may not drop a client like a hot potato." ${ }^{\prime 3}$ When a case falls within the doctrine and is not excluded by any of the principles discussed in the previous section, just two things follow. First, the case must be appraised under the professional rules governing concurrent client conflicts, not those

79. This analysis does not apply, for example, when a lateral hire or merger is tantamount to entering into a forbidden representation because the main case that a lateral brings to the new firm conflicts with one of the firm's existing representations.

80. See, e.g., A. v. B., 726 A.2d 924 (N.J. 1999) (holding that firm could share information with wife).

81. See, e.g., Whiting v. Lacara, 187 F.3d 317, 322-23 (2d Cir. 1999) (involving client who threatened to sue lawyer); Fiandaca v. Cunningham, 827 F.2d 825 (1st Cir. 1987) (involving defendant who proposed relief that would benefit plaintiff class at the expense of another class that the same lawyers represented in another suit); ABA Comm. on Ethics \& Prof'l Responsibility, Formal Op. 94-384 (1994) (opposing party files grievance against lawyer); RESTATEMENT (THIRD) OF THE LAW GOVERNING LAWYERS $\S 132$ illus. 6 (2000) (opposing party unexpectedly calls lawyer's former client as witness).

82. See, e.g., SuperGuide Corp. v. DirecTV Enters., 141 F. Supp. 2d 616 (W.D.N.C. 2001) (involving defendant that impleaded party that firm representing plaintiff had formerly represented in related matter).

83. Picker Int'l, 670 F. Supp. at 1365. 
governing past client conflicts. ${ }^{84}$ Second, any attempt by the law firm in question to continue representing its new client without informed consent will be met with judicial suspicion and very likely a disqualification order.

But there is a gap between "very likely" and "always" that leaves open two questions: who is to decide whether the presumption of disqualification should be overridden, and what standards should govern that decision? Just as finding that a conflict was "thrust upon" the firm and not its fault does not tell us which representation should be dropped, finding that a firm has violated the hot potato doctrine does not tell us what should happen next. ${ }^{85}$

\section{A. Judicial Discretion and Its Alternatives}

Although there have been suggestions that, granted a concurrent client conflict, the firm must withdraw from both representations, that makes sense only in a limited class of situations, those in which the concurrent representations are related. ${ }^{86}$ When the representations are related, the firm may be assumed to have received confidential information in each representation that could be used in the other, and the past client rules therefore forbid the firm from representing either client even after it drops the other one. ${ }^{87}$

When the representations are not related in this sense, forbidding both of them simply doubles the pain inflicted on clients by rules intended to protect them. Once one representation ends, the problems raised by concurrent representations also end, and if the representations are unrelated, then the problems raised by successive representations are also absent. Double disqualification would indeed be a powerful deterrent for law firms, but the collateral harm it inflicts is unacceptable. Even if it were necessary to sanction a firm by denying it the benefit of

84. See supra Part II.

85. See supra text accompanying notes 67-72.

86. The results in some cases are consistent with this view. See, e.g., Stratagem Dev. Corp. v. Heron Int'l N.V., 756 F. Supp. 789 (S.D.N.Y. 1991); In re Grieb Printing Co., 297 B.R. 82, 89 (Bankr. W.D. Ky. 2003); Margulies v. Upchurch, 696 P.2d 1195 (Utah 1985); see also RotUNDA \& DZIENKOWSKI, supra note 9, at 339 ("Absent special circumstances, if the parties do not consent to the conflict, the law firm must withdraw from representing both parties in the two cases." (footnote omitted)). But see MoDEL RULES OF PROF'L CONDUCT R. 1.7 cmt. 4 (2010) ("Where more than one client is involved, whether the lawyer may continue to represent any of the clients is determined both by the lawyer's ability to comply with duties owed to the former client and by the lawyer's ability to represent adequately the remaining client or clients, given the lawyer's duties to the former client.”); RESTATEMENT (THIRD) OF THE LAW GOVERNING LAWYERS $§ 121$ cmt. e (2000) (discussing appropriateness of withdrawal in different conflicts situations).

87. See Model Rules of Prof’L Conduct R. 1.9(a) (2010). 
both representations, that could be accomplished by ordering the firmthose involved in hot potato cases are typically large and wealthy-to stay in one case but serve without pay. ${ }^{88}$

Another clear, simple, and unacceptable rule is suggested by the language of some courts: the firm may not drop its old client - that being precisely what the hot potato doctrine is supposed to forbid-and must therefore drop the new client, absent informed consent or grounds that would warrant withdrawing from the old representation even in the absence of a conflict of interest. ${ }^{89}$ Such a requirement would deter firms from undertaking the new representation, ensure that improper concurrent representations would be ended, and discourage wasteful litigation over the appropriateness of disqualification. But as we shall see, hot potato cases differ among themselves in relevant ways that focusing on a paradigm case can obscure, and in some cases numerous practical concerns can cut against disqualification. ${ }^{90}$

Granting that some kind of case-by-case approach will therefore be desirable, entrusting it to the firm in question has the obvious flaw that the firm has just demonstrated poor judgment, if not worse, by accepting two clients in violation of the concurrent representation rule, and then jettisoning the older client in defiance of the hot potato doctrine. Nevertheless, some initial decision by the firm seems unavoidable, if only because client objections will usually be presented to the firm before they are submitted to the court. Sometimes, indeed, they will never reach the court, either because the parties and firm reach agreement on a resolution, or because the conflict does not involve a case in litigation and no one chooses to bear the burden of initiating a court proceeding. And sometimes the firm's decision seems untainted by past mistakes or present self-interest. ${ }^{91}$

88. See Dewey v. R.J. Reynolds Tobacco Co., 536 A.2d 243, 251-53 (N.J. 1988) (imposing this sanction). For other possible sanctions, see supra text accompanying notes 56-59.

89. See, e.g., Int'l Bus. Mach. Corp. v. Levin, 579 F.2d 271 (3d Cir. 1978); Truck Ins. Exch. v. Fireman’s Fund Ins. Co., 8 Cal. Rptr. 2d 228 (Cal. Ct. App. 1992). On other grounds for withdrawal, see supra text accompanying notes 40, 43. In support of automatic disqualification for violations of conflicts rules, see, for example, In re Am. Airlines, Inc., 972 F.2d 605, 609-12 (5th Cir. 1992); RoTUNDA \& DZIENKOWSKI, supra note 9, at 506. For contrary authority, see infra notes 93-96.

90. See infra Part IV(B).

91. See, e.g., Stratagem, 756 F. Supp. 789 (allowing firm to withdraw from both representations). 
Setting aside the possibilities of decision by a simple and unbending rule, or by the law firm whose conduct is in question, leaves it to the court before which one of the conflicting representations is pending to decide which client should be dropped. The contending clients can present the relevant facts and arguments to the court, which can then render a speedy decision. That is not true of the disciplinary authorities, which are much slower and rarely sanction the large-firm lawyers in complex and disputed factual situations who are involved in most reported hot potato cases. ${ }^{92}$

Several lines of argument support the discretion of a court confronting a hot potato problem to balance all the relevant factors in deciding which representation the offending firm should drop. When a party to a case or intervenor moves to disqualify its lawyer or former lawyer from continuing its representation of another party, there is substantial authority that even a clear violation of a professional rule does not necessarily require disqualification. ${ }^{93}$ Likewise, if a lawyer seeks to withdraw from a pending court representation, the court has discretion in deciding whether to allow withdrawal. ${ }^{94}$

Furthermore, the hot potato doctrine is not a rule embodied in fixed language that a court may not inflect. It is a court-created doctrine based on ethical and policy concerns, and courts should be free to deny disqualification when in particular circumstances those concerns are outweighed by others. Indeed, hot potato cases by definition involve two unrelated representations, and because the arguments for applying the concurrent representation rule to such cases are often weak to begin with, courts should exercise a broader discretion to withhold disqualification than they would in other situations. ${ }^{95}$ For one or another of these

92. On the proper role of courts in disqualification cases, compare Bruce A. Green, Conflicts of Interest in Litigation: The Judicial Role, 65 FordHAM L. REV. 71 (1996), with Susan R. Martyn, Developing the Judicial Role in Controlling Litigation Conflicts: Response to Green, 65 FORDHAM L. REV. 131 (1996).

93. See, e.g., United States v. Miller, 624 F.2d 1198, 1201 (3d Cir. 1980); Bd. of Educ. v. Nyquist, 590 F.2d 1241, 1245-46 (2d Cir. 1979); RESTATEMENT (THIRD) OF THE LAW GOVERNING LAWYERS § 6 cmt. i \& reporter's note (2000); supra note 17; see also Wheat v. United States, 486 U.S. 153, 163-64 (1988) (stating that the court has discretion to require disqualification even though criminal defendants affected by conflict consent). For authority supporting a more automatic disqualification rule, see supra note 89.

94. See, e.g., Patterson v. Gemini Org., Ltd., No. 99-1537, 2000 WL 1718542 (4th Cir. Nov. 17, 2000); Whiting v. Lacara, 187 F.3d 317, 320-21 (2d Cir. 1999); AnNotAted Model Rules of Prof'L Conduct R. 1.16 cmt., at 247-48 (6th ed. 2007).

95. See Morgan, supra note 7. Of course many people reject Morgan’s critique. My own view is that being sued by "one's own lawyer" in an unrelated matter is painful but rarely imposes improper burdens on the client. Normally, therefore, I would not allow the client in that situation to object. On the other hand, being represented by a lawyer who simultaneously represents one's opponent in an unrelated matter does create a risk of 
reasons, there is significant authority upholding the discretionary approach in hot potato cases. ${ }^{96}$

\section{B. What Courts Should Consider in Exercising Discretion}

Courts exercising discretion in hot potato cases typically rely on obvious practical concerns relating to the speedy and economical resolution of the cases before them. Sometimes circumstances that should be considered in deciding whether a firm has behaved improperly reappear with questionable appropriateness as part of a conglomerate discretionary decision. And sometimes courts stir into the stew factors that are equally present in other kinds of cases and should ordinarily be treated by more general rules. I will discuss instances of these phenomena here without claiming to cover all of them or to lay down a general standard for the exercise of discretion.

\section{Balancing Client Burdens}

Because the conflict of interest rules are meant to protect clients, it makes sense to relax their application, even at the cost of some deterrence of future violations, when they would seriously injure clients. So courts are less willing to disqualify counsel when the suit is already well advanced ${ }^{97}$ and bringing in new counsel would consume time and money ${ }^{98}$ than when that is not the case. And they are more willing to disqualify when the client to be bereaved already had another firm on the

faint-hearted representation and should be permissible only with the client's informed consent.

96. See, e.g., Metro. Life Ins. Co. v. Guardian Life Ins. Co., No. 06 C 5812, 2009 WL 1439717 (N.D. Ill. May 18, 2009); Bd. of Regents of the Univ. of Neb. v. BASF Corp., No. 4:04CV3356, 2006 WL 2385363 (D. Neb. Aug. 17, 2006); Eastman Kodak Co. v. Sony Corp., No. 04-CV-6095, 04-CV-6098, 2004 WL 2984297 (W.D.N.Y. Dec. 27, 2004); Research Corp. Techs., Inc. v. Hewlett-Packard Co., 936 F. Supp. 697, 70103 (D. Ariz. 1996); SWS Fin. Fund A v. Salomon Bros., 790 F. Supp. 1392 (N.D. Ill. 1992).

97. See, e.g., Eastman Kodak, 2004 WL 2984297; Universal City Studios, Inc. v. Reimerdes, 98 F. Supp. 2d 449, 456 (S.D.N.Y. 2000); Hewlett-Packard, 936 F. Supp. at 702; Carlyle Towers Condo. Ass'n v. Crossland Sav., FSB, 944 F. Supp. 341, 349 (D.N.J. 1996); Molina v. Mallah Org., 804 F. Supp. 504, 512 (S.D.N.Y. 1992).

98. See, e.g., Installation Software Techs., Inc. v. Wise Solutions, Inc., No. $03 \mathrm{C}$ 4502, 2004 WL 524829 (N.D. Ill. Mar. 2, 2004); Gould, Inc. v. Mitsui Mining \& Smelting Co., 738 F. Supp. 1121, 1126-27 (N.D. Ohio 1990). 
job $^{99}$ or could easily find one. ${ }^{100}$ These concerns should lie at the heart of the court's consideration whether to disqualify the offending firm.

\section{Discounting or Emphasizing Client Burdens}

Sometimes a client's own acts warrant treating less seriously its claims of harm. We have seen one example of this in the thrust upon cases, where the concurrent representation problem is attributed to the client and sanctioning the firm would be inappropriate. ${ }^{101}$ But even when the firm has erred, courts may reject disqualification if they conclude that a client has delayed unreasonably in reacting or is primarily motivated by tactical advantage. ${ }^{102}$

There is one situation in which heightened sympathy for a firm's "new client" may be in order because it is really an old client. Suppose Firm has represented FreezeFries, Inc. for many years in many matters, none of them against FreezeFries's competitor, HotFries, Co. HotFries retains Firm for a tax matter. Soon afterward, HotFries - using other counselsues FreezeFries, which calls on Firm to defend it. Under the concurrent representation rule, Firm's pending representation of HotFries precludes its accepting the case. ${ }^{103}$

If Firm now drops HotFries without its consent, it has violated the hot potato doctrine. Such a withdrawal does not count for conflict of interest purposes and leaves Firm subject to, and in violation of, the concurrent representation rule. The decision that rule governs is the decision to accept a new representation, whether or not it involves a new client. In that respect, this Article has sometimes risked being misleading by speaking of old and new clients, rather than old and new representations. Even if Firm has long represented FreezeFries in other matters, it is under no professional obligation to accept a new representation. ${ }^{104}$ And even if it has just started representing HotFries, that client is entitled to have counsel not subject to perverse incentives or grounds for legitimate distrust, such as those created by a conflicting

99. See, e.g., Salomon Bros., 790 F. Supp. 1392.

100. See, e.g., Eaton v. Coca-Cola Co., 640 F. Supp. 2d 203 (D. Conn. 2009) (scoffing at Pepsi's claim of hardship).

101. See supra Part III(C).

102. See, e.g., Flying J Inc. v. TA Operating Corp., No. 1:06-CV-30 TC, 2008 WL 648545 (D. Utah Mar. 10, 2008); Universal City Studios, 98 F. Supp. $2 d 449$.

103. See Model Rules of Prof'L ConduCt R. 1.7(a) (2010).

104. See RESTATEMENT (THIRD) OF THE LAW GOVERNING LAWYERS $\S 14 \mathrm{cmt}$. b (2000). In England, the "Cab-Rank Rule" obliges barristers to accept clients, but the many exceptions include situations in which acceptance would cause a conflict of interests. See Code Of Conduct of THE BAR of ENGLAND AND WALES R. 602, 603(e) (8th ed. 2004), available at http://www.barstandardsboard.org.uk/assets/documents/8th\%20Edition\% 20of\%20the\%20Code\%20of\%20Conduct\%20-\%206\%20October\%202010.pdf. 
concurrent representation. Only if the new case can somehow be considered as part of a representation antedating the HotFries representation could this logic be avoided.

On the other hand, cases in which a firm drops a new representation for the sake of an old client are far from the paradigm that gave rise to the hot potato doctrine. That difference may help support a denial of disqualification. Even if FreezeFries's suit is a new matter, FreezeFries may well have-depending on its outside counsel practices ${ }^{105}$ educated, confided its secrets to, and placed its trust in Firm over the years. Forcing it to turn elsewhere in its hour of need may be even more jarring and costly for FreezeFries than interrupting Firm's new representation of HotFries. For its part, Firm may be driven less by the search for the most lucrative client than by a sense of loyalty to good old FreezeFries. It is even possible that HotFries's single case will earn Firm more than all the matters it hopes to handle for FreezeFries. In such a situation, requiring Firm to drop the defense of FreezeFries and continue its representation of HotFries may not be needed as a sanction to prevent future offenses and may disproportionately burden FreezeFries.

Relying on judicial discretion provides a reasonable way out of this dilemma. The court can rule that a firm has indeed violated the concurrent representation rule by accepting a new case pitting an old client against a new one. At the same time, it may consider the firm's traditional representation of the old client as one factor, albeit not conclusive, in assessing the harm that termination would inflict on each client and the appropriateness of disqualification. ${ }^{106}$

\section{Reducing Client Burdens}

If an old client can be protected against the harms assumed to flow from concurrent representation and from being dropped by a firm, there

105. See David B. Wilkins, Team of Rivals? Toward a New Model of the Corporate Attorney-Client Relationship, 78 FordHAM L. REV. 2067 (2010). As Professor Wilkins explains, some corporations use many outside firms, retaining whichever one seems most appropriate for the matter in question. See id. at 2085-92. If either FreezeFries or HotFries does this, its claims that losing Firm's assistance will be disruptive are less weighty.

106. See, e.g., Bayshore Ford Truck Sales, Inc. v. Ford Motor Co., 380 F.3d 1331 (11th Cir. 2004); Forrest v. Baeza, 67 Cal. Rptr. 2d 857 (Cal. Ct. App. 1997). But see Stratagem Dev. Corp. v. Heron Int'l N.V., 756 F. Supp. 789 (S.D.N.Y. 1991) (rejecting this argument). 
is less reason to disqualify the firm from continuing to represent its new client. Some courts have asserted that this may be done by screening the firm's lawyers involved in one representation from those involved in the other. ${ }^{107}$

The logic of screens, cones of silence, ethical walls, or the like in this situation is dubious. The main purpose of such arrangements is to prevent confidential information from one representation being misused in another one. ${ }^{108}$ But in hot potato cases there is no real danger of sharing confidential information because the representations in question are by hypothesis unrelated. ${ }^{109}$ Screening can remove one problem invoked to justify the concurrent representation rule-the embarrassment for a client of consulting with a lawyer in one representation while knowing that the lawyer represents one's opponent in another. And screening might sometimes-but by no means always or even usuallyreduce another problem justifying the concurrent representation rulethe possibility that a firm would reduce the vigor of its representation against a client it represents in another matter for fear that it will lose the second representation. In an "eat-what-you-kill" firm in which lawyer self-interest rules, ${ }^{110}$ confiding each representation to a separate group of lawyers might perhaps ensure that each group would zealously pursue its client's interests, heedless of the impact on the firm as a whole. But to the extent that firm lawyers believe that they are involved in a common enterprise, or are afraid of retaliation by other lawyers blaming them for a client's departure, no such result will follow.

For these reasons, I would grant little or no weight to a law firm's unilateral screening as a factor cutting against disqualification in a hot potato case. That leaves room for screening by mutual agreement, as part of an old client's informed consent to a firm's undertaking a new representation. There may also be other ways in which a court may shape relief to reduce the dangers of concurrent representation. For example, a court might require, as a condition of denying disqualification,

107. See, e.g., Flying J Inc. v. TA Operating Corp., No. 1:06-CV-30 TC, 2008 WL 648545 (D. Utah Mar. 10, 2008) (a hot potato case). For a similar assertion in a concurrent representation case not involving a hot potato problem, see Wyeth v. Abbott Laboratories, 692 F. Supp. 2d 453 (D.N.J. 2010).

108. See Model Rules of Prof'L Conduct R. 1.10(a)(2), 1.11(b) (2010); RESTATEMENT (THIRD) OF THE LAW GOVERNING LAWYERS § 124 (2000).

109. See Concat LP v. Unilever, PLC, 350 F. Supp. 2d 796, 821-22 (N.D. Cal. 2004) (making this point). If the representations were related, the new one would continue to be barred by the former client rule even after the firm dropped its old client. See supra text accompanying note 24 .

110. See generally Milton C. Regan JR., Eat What You Kill: The Fall of a Wall Street Lawyer (2004); Milton C. Regan, Jr., Law Firms, Competition Penalties, and the Values of Professionalism, 13 GEO. J. LEGAL ETHICS 1 (1999). 
that a firm offer a contingent fee arrangement to the client that has reason to fear that the firm will slack off in representing it.

\section{The Firm's Fault}

Because disqualification is, among other things, a sanction for lawyer misbehavior, it makes sense to consider a firm's delay in finding ${ }^{111}$ or remedying ${ }^{112}$ a conflict of interest as a factor in favor of disqualifying it.

Some courts have gone beyond this to rank the firm's greed level, discussing how lucrative each of the clients in question would have been. ${ }^{113}$ But relying on the lucrativeness of the new representation as a factor affecting disqualification makes little sense. Courts are not likely to be very good at predicting what revenue one or another client will yield. Indeed, even law firms, however avaricious in principle, may fail in their predictions. In any event, whether a client is likely to pay well over the years tells one nothing about how severely loss of its lawyers' services will hurt it now, which should be the central concern in deciding which client should yield. And whether a firm has exposed to a conflict a more or less lucrative client says little about the need for sanctions. This is one instance in which the natural feelings of shock that gave rise to the hot potato doctrine have misled some judges.

\section{Quasi-Clients: Corporate Affiliates}

There has been much discussion about when a law firm representing one corporation in a corporate family should be treated as representing other members of that family for conflicts of interest purposes. ${ }^{14}$

111. See, e.g., Lemelson v. Apple Computer Inc., No. CV-N-92-665-HDM (PHA), 1993 WL 556452 (D. Nev. June 2, 1993); Atl. Pac. Home Loans, Inc. v. Superior Court, No. D048609, 2006 WL 3616997 (Cal. Ct. App. Dec. 13, 2006). But see Research Corp. Techs., Inc. v. Hewlett-Packard Co., 936 F. Supp. 697, 703 (D. Ariz. 1996) (dismissing as "inadvertent" a serious failure to detect conflict).

112. See supra note 77.

113. See, e.g., Eaton v. Coca-Cola Co., 640 F. Supp. 203 (D. Conn. 2009) (comparing Coke and Pepsi); Santacroce v. Neff, 134 F. Supp. 2d 366, 371 (D.N.J. 2001) (involving firm that preferred "the extraordinarily more remunerative client"); Apple Computer, 1993 WL 556452 (discussing individual client's wealth and litigativeness); Unanue v. Unanue, No. Civ. 204-N, 2004 WL 602096 (Del. Ch. Mar. 25, 2004) (contrasting this case to those in which lawyer drops small client for large one).

114. See, e.g., ABA Comm. on Ethics \& Prof'l Responsibility, Formal Op. 95-390 (1995); RESTATEMENT (THIRD) OF THE LAW GOVERNING LAWYERS § $121 \mathrm{cmt}$. d (2000); Ronald D. Rotunda, Conflicts Problems When Representing Members of Corporate 
Suffice it to say that, when it comes to concurrent client conflicts, courts are likely to treat as identical a corporation and its wholly owned subsidiary when they share in-house counsel and officers, ${ }^{115}$ or when a judgment against the subsidiary would have a substantial financial impact on the parent. ${ }^{116}$ One case treating this issue in the hot potato doctrine follows a similar approach, ${ }^{117}$ while two older decisions simply treat parents and subsidiaries as identical without considering the circumstances. $^{118}$

Should a court considering a hot potato case in which a firm represented one member of a corporate family but another member seeks disqualification consider that circumstance in deciding whether to exercise its discretion to deny disqualification? The question does not arise if the court concludes that the two corporations should be considered separate because that conclusion leads to a holding that there was no violation of the concurrent representation rules and hence no claim for disqualification calling for the exercise of judicial discretion. But if the court treats the corporations as one and finds a violation, the firm and its preferred client can still assert that the violation verged on the merely technical. It can argue that the harms threatened by the conflict are diluted by the fact that the suit in which disqualification is sought involves one corporation while the firm has represented only its parent or subsidiary. Indeed, two courts finding a violation in circumstances like these have nevertheless withheld disqualification because, among other reasons, the complaining client was not really harmed by the concurrent representations. ${ }^{119}$

Families, 72 Notre Dame L. Rev. 655 (1997); Charles W. Wolfram, Corporate-Family Conflicts, 2 J. Inst. FOR STUDy LEGAL ETHICS 295 (1999).

115. See, e.g., GSI Commerce Solutions, Inc. v. BabyCenter, L.L.C., 618 F.3d 204 (2d Cir. 2010); Honeywell Int'l, Inc. v. Philips Lumileds Lighting Co., No. 2:07-CV463-CE, 2009 WL 256831 (E.D. Tex. Jan. 6, 2009).

116. See, e.g., Cliffs Sales Co. v. Am. S.S. Co., No. 1:07-CV-485, 2007 WL 2907323 (N.D. Ohio Oct. 4, 2007); see generally Wolfram, supra note 61, at 52-53. Sometimes both factors mentioned in the text are present and support disqualification. See, e.g., Certain Underwriters at Lloyd's, London v. Argonaut Ins. Co., 264 F. Supp. 2d 914 (N.D. Cal. 2003); JPMorgan Chase Bank v. Liberty Mut. Ins. Co., 189 F. Supp. 2d 20 (S.D.N.Y. 2002).

117. See Eastman Kodak Co. v. Sony Corp., No. 04-CV-6095, 04-CV-6098, 2004 WL 2984297 (W.D.N.Y. Dec. 27, 2004) (treating parent and subsidiary sharing legal department and officers as one).

118. See Stratagem Dev. Corp. v. Heron Int'l N.V., 756 F. Supp. 789 (S.D.N.Y. 1991); Gould, Inc. v. Mitsui Mining \& Smelting Co., 738 F. Supp. 1121, 1125-26 (N.D. Ohio 1990).

119. See Carlyle Towers Condo. Ass'n v. Crossland Sav., FSB, 944 F. Supp. 341, 349 (D.N.J. 1996); Gould, 738 F. Supp. 1121; see also Cliffs Sales, 2007 WL 2907323 (using a similar approach, but not in a hot potato case). 
I would reject reliance on this factor to cut against disqualification in cases in which the court's decision to treat two corporations as one was based, as it should be, on a showing that the corporations share counsel and management, or that a decision harming one will significantly harm the other as well. ${ }^{120}$ That showing imports a finding that the dangers of concurrent representation will indeed be present despite the split in corporate form. Allowing a challenge to that finding as a reason to deny disqualification stirs together two bodies of professional responsibility law - the hot potato doctrine and the corporate-family decisions-each of which is already more than sufficiently confusing.

But I would reach a different result if the court is one of those that amalgamates parent and subsidiary, not on the basis of specific findings that establish a danger warranting application of the concurrent representation rule, but because of more general evidence that a parent and subsidiary constitute a single economic unit, and the court's belief that economic unity should normally make the two corporations a single unit when the conflict of interest rules are applied. ${ }^{121}$ This approach scarcely consists with our usual respect for the corporate veil. ${ }^{122}$ And a finding of corporate identity without a substantial showing that the circumstances justifying the concurrent representation rule are present fails to provide an adequate basis for applying that rule without exception. The opposing party and the law firm in question should therefore be free to contend that, because of the corporate split and the circumstances associated with it, harm is not likely enough to warrant disqualification.

\section{Quasi-Clients: Accommodation Clients}

A similar problem concerns the argument that disqualification is not required because one of the concurrent clients is a mere "accommodation" client:

120. See supra notes 115-17.

121. See, e.g., Discotrade Ltd. v. Wyeth-Ayerst Int'l, Inc., 200 F. Supp. 2d 355, 358-59 (S.D.N.Y. 2002) (treating two corporations as one on basis of a somewhat general showing); Gen-Cor, LLC v. Buckeye Corrugated, Inc., 111 F. Supp. 2d 1049, 1053 (S.D. Ind. 2000); Univ. of Rochester v. G.D. Searle \& Co., No. 00-CV-6161L(B), 2000 WL 1922271 (W.D.N.Y. Dec. 11, 2000); ABA Comm. on Ethics \& Prof'l Responsibility, supra note 114; supra note 118.

122. See Rotunda, supra note 114. 
With the informed consent of each client ... a lawyer might undertake representation of another client as an accommodation to the lawyer's regular client, typically for a limited purpose in order to avoid duplication of services and consequent higher fees. If adverse interests later develop between the clients, even if the adversity relates to the matter involved in the common representation, circumstances might warrant the inference that the "accommodation" client understood and impliedly consented to the lawyer's continuing to represent the regular client in the matter. ${ }^{123}$

Courts have sometimes treated accommodation clients as having implicitly waived their right to object to the joint lawyer's representing the main client against them, but such rulings have also been criticized as weakening the standards for informed consent to a conflict of interest. ${ }^{124}$ Parties in hot potato cases have also raised accommodation client arguments, with mixed success. ${ }^{125}$

In this situation, I can see no reason to rely on accommodation client claims as a factor bearing on the court's discretion not to disqualify. ${ }^{126}$ The meaning of being an accommodation is that the client has implicitly but validly consented to its lawyer's accepting certain representations that conflict of interest rules would otherwise forbid. If the challenged representation is one of those consented to, it is of course permissible, and there is no occasion to disqualify the firm in question. If the representation does not fall within the client's consent, its having been an accommodation client that consented to other representations is simply irrelevant to the representation in question. True, questions may be raised as to the scope of the client's consent, but these should be resolved on their merits, not used to garnish the hot potato doctrine. Discretion is often a fine thing, but care must be taken that it is not rendered incoherent and arbitrary by the invocation of concerns more properly treated elsewhere.

123. Restatement (THIRD) OF THE LAW GOVERning LAWYERS § $132 \mathrm{cmt}$. i (2000). The leading case is Allegaert v. Perot, 565 F.2d 246 (2d Cir. 1977).

124. See Douglas R. Richmond, Accommodation Clients, 35 AKRON L. Rev. 59 (2001). For cases applying or rejecting the doctrine, see FlAMM, supra note 23, § 10.6.

125. See Sabrix, Inc. v. Carolina Cas. Ins. Co., No. CV-02-1470-HU, 2003 WL 23538035 (D. Ore. July 23, 2003) (involving facts that raised an accommodation client problem, but the court denied disqualification without mentioning this). Compare G.D. Searle \& Co., 2000 WL 1922271 (holding that party seeking disqualification was accommodation client is one factor supporting denial of disqualification), with Universal City Studios, Inc. v. Reimerdes, 98 F. Supp. 2d 449 (S.D.N.Y. 2000) (holding that client was not accommodation client, and even had it been, that would not justify firm's withdrawal).

126. Contra G.D. Searle \& Co., 2000 WL 1922271. 


\section{CONCLUSION}

The hot potato doctrine turns out to have several layers. On the outside, we find an expression of outrage against lawyers who abandon one client for another. Peeling this away, we reach what purports to be a precise rule stating that firms who drop clients without cause will be treated for conflict of interest purposes as though they had not done so. The rule thus completes the formal structure of the Model Rules, stating when the concurrent representation rule ${ }^{127}$ will apply and eliminating the perverse incentives for lawyers created by the difference between that rule and the former client rule. ${ }^{128}$ That appears to be the meat of the doctrine, but probing deeper we find a large and mushy core, in which courts frequently let the doctrine remain unenforced by exercising their discretion to deny disqualification in the light of many more or less relevant factors. Here, the various problems and concerns that the doctrine was supposed to resolve reappear in the form of arguments for or against disqualification.

Do we need the hot potato doctrine? Why not simply say that a court may, after considering all relevant factors, disqualify a firm that accepts a representation forbidden by the conflicts rules or withdraws from a representation without adequate grounds? ${ }^{129}$ Such a formulation would probably work but would still leave us with most of the problems I have discussed here. For example, we would still have to think about what difference it makes if the client causes the problem by merging with another corporation, or if it discharges the firm rather than being dropped, or if the new representation is of an old client. And of course we would lose a colorful simile and the opportunity for some fun. I like to think that Fred Zacharias would have enjoyed that.

127. Model Rules of Prof’́ Conduct R. 1.7(a)(1) (2010).

128. Id. R. 1.9(a).

129. Although I refer here only to disqualification, other remedies are of course also available. See supra text accompanying notes 56-59. 
